\title{
Big Data Applications in Businesses: An Overview
}

\author{
Raza Ur Rehman Qazi ${ }^{1}$, Ali Sher ${ }^{2}{ }^{*}$ \\ ${ }^{1}$ College of Computer and Information Sciences, Imam Muhammad Ibn Saud University, \\ Riyadh, Kingdom of Saudi Arabia \\ ${ }^{2}$ Faculty of Business, University of New Brunswick, \\ 100 Tucker Park Road, \\ Saint John, NB E2L 4L5, Canada \\ E-mail: asher@unb.ca
}

\begin{abstract}
Many businesses are implementing big data applications to improve efficiency and performance; and reduce costs and resource consumption. As digitization has become an integral part of everyday life, data collection has resulted in the accumulation of huge amounts of data that can be used in various beneficial application domains. Effective analysis and utilization of big data is a key factor for success in many businesses. This paper reviews the applications of big data to support businesses in key areas including E-Commerce, Human Resources, Customer Relationship Management, and Accounting. The review reveals that big data concepts are being used successfully and businesses have harvested it benefits both in financial and non-financial terms. The competitive nature of businesses that have emerged from enabled insight prompts for every business to ensure that they reap meaningful information from the internet and use it to create a business opportunity. Consequently, the significance of big data in developing value that can be turned to a potential commercial gap, created from insight, which can be exploited remains an area that has limited exploration from analytics in the discipline. It remains critical to evaluate the efficient business insight strategies that can be developed to ensure an optimized value addition that is based on accurate insight from the wild count of data source. Additionally, the study reveals that several opportunities are available for utilizing Big Data in different types of businesses; however, there are still many issues and challenges to be addressed to achieve better utilization of this technology. Consequently, there is much that remain unexplored on efficient Big Data approaches that can be used to gain value for business, especially now a time of acute business competition.
\end{abstract}

Keywords: Big Data, Big Data Analytics, E-Commerce

${ }^{*}$ Corresponding author. 


\section{Introduction}

Over the past 20 years, an immense surge in the amount of data generated by businesses led to difficulty in managing the large amount of data especially with the traditional data management tools. This led to the emergence of a new idea, Big Data. The simplest definition of Big Data is by Webopedia that states "Big Data is" a massive volume of both unstructured and structured data so large that it's difficult to process using traditional database and software techniques". "Unstructured" data refers to videos, emails, tweets etc., while "structured" data refers to data such as customer data, name, address, ZIP CODE etc., stored in a wellorganized manner.

Gantz and Reinsel (2012) defined Big Data in a more complex way in terms of three characteristics: the data itself, the analytics of the data, and the presentation of the results. Big Data has also been defined by White (2012) through five Vs. These five "Vs" stand for volume (quantities of big data), variety (different types of data), veracity (the reliability of data sources), velocity (the speed of data collection, processing and analyzing in real time), and value (the transactional, strategic and informational benefits of big data) (Wixom et al., 2013). Research in academia and the industry has provided enough proof to highlight the importance of Big Data in the different functionalities of E-Commerce. For instance, Big Data plays a crucial role in human resources, management, marketing, production \& operation management, and finance (Agarwal \& Weill, 2012; Bose, 2009; Davenport et al., 2012).

The applicability of data is not gained from mere analytics. The value obtained from analyses of data must be through proper insight that is business oriented (McAfee et al., 2012). Most business entities, however, have failed to identify the business opportunity that can be realized; due to poor insight. Kandogan et al. (2013) indicate that value from decent idea can be used to gain a competitive advantage. A great business insight must be thought that is out of the ordinary. Typical data analysis entails formats that are based on geography, year and product line. A typical insight could regard a critique of the data using different categorization, such as using climatic and festive seasons. Developing such unique approaches demand to answer open-ended yet insightful questions. Kandogan et al. (2013) explain that experts use this kind of data analysis technique to scrap vital and surprisingly uncommon information from web pages.

Developing such information in a business-oriented format remains a challenge that can only be overcome using a proper combination of effort from technical analyzers and senior business leaders. Proper interpretation of these significant data analysis results translates to an upper hand in the competitive business world. McAfee et al. (2012) explain that measuring, in a view to understanding the dataset is critical before any processing steps are initiated. Among the data scrapped from the web is customer satisfaction, this entails understanding the current demand, and the likely market trends from a projection of ongoing activities. However, useful trajectories can be developed only if there is correct necessary information about the concept under analysis (Bollier \& Firestone, 2010). Forecast development is a strong insight strategy that can lead to regulating losses from unforeseen yet projected commercial incidences.

While developing such data demands time and technical experts, initiating techniques that can be used to deliver the information in time will add even more value as the information produced by the quickest company will lead to more gain, before competitors may copy it, or discover it as well (McAfee et al., 2012). At times, developing proper insight may require more time and programming techniques. Converting the raw data to meaningful information remains a challenge. All in all, the problem of converting raw data to useful has been overcome by software that may optimize search engines. In spite of this significant development, in processing raw data from the web, answering customized prompts that are unique and insightful has not been achieved. The subjective nature of this kind of analysis has prompted a direct involvement of every business person who is interested in gorging information from the internet to directly get involved in extracting the information.

E-Commerce, a new chapter in web based business operations has been enriched with computer aided innovations. As indicated above, identifying unique, commonly unnoticed, business opportunities is not easy. This gives the big companies an advantage as they can use their experts and the web-based information gorging techniques to reap excellent business prospects. Using a clearly developed management format, business is inventing new opportunities, by phasing concepts of 
business administration strategies, patents management, and idea management. Open innovation process uses the toolkits for open innovation, as Hüsig and Kohn (2011) indicate. The approach uses product test designs, prototyping, and design testing tools so that the testing samples can be reviewed by the end users. The method appears fit as it saves on cost cautions impending dangers in any business venture.

The core purpose of any business entity is to develop products that have a value within a given market, by making sure that what is produced is what is needed. While Big Data application in business is geared towards most of the business operations, hardly has there been any successful integration of the technology with business oriented production activities. However, to explore efficient methods of exploring this gap, proper understanding of the role of Big Data in the business process is critical. Once the role of Big Data is understood, improving its technological wealth with a business-oriented line of thought is easy. Ideally, the value of Big Data is optimally realized if its technical functionality is merged with customized businesses notion, for a particular organization.

This paper presents the review of the applications of Big Data that support businesses in key areas including E-Commerce, Human Resources, Customer Relation- ship Management, Accounting, and Supply Chain. This paper is further sub-divided into three main sections. The first section of the paper describes the role of Big Data in e-commerce. The second section describes applications of Big Data in several business functions. The third section discusses conclusion.

\section{Big Data in E-Commerce}

Big Data's main goal is to generate business value (Beath et al., 2012). Value here stands for the derivation of economically meaningful information through the analysis of Big Data. For the purpose of this article, the definition given by Wixom et al. (2013) will be used. Wixom defines business value as the transactional, informational and strategic benefits for the e-commerce firms. The transactional value means improvement in efficiency and cost reduction while informational value refers to the benefit of real-time decision making. Strategic value is the gain of competitive advantage. According to Columbus (2014), E-Commerce firms could benefit from the Big Data analytics in terms of customer needs $(79 \%)$, creating new products and services $(70 \%)$, expanding into new markets $(72 \%)$, and increasing sales and revenue $(76 \%)$.

Table 1: E-Commerce Mechanisms and Business Value

\begin{tabular}{|c|l|}
\hline $\begin{array}{c}\text { Mechanism } \\
\text { Name }\end{array}$ & \multicolumn{1}{c|}{ Business Value gained by the use of Big Data } \\
\hline Personalization & $\begin{array}{l}\text { provided personalized service or customized products like special offers and promotions to its customers } \\
\text { to increase ROI and reduce the marketing expenditure (Jao, 2013; Kopp, 2013; Mehra, 2013; Miller, 2013; } \\
\text { Zhao, 2013). }\end{array}$ \\
\hline $\begin{array}{c}\text { Dynamic pricing } \\
\text { Customer service }\end{array}$ & $\begin{array}{l}\text { setting a competitive price (Kopp, 2013; Kung et al., 2013) to increase sale. For example, Amazon sales } \\
\text { has increased 35\% by using the price monitoring system. }\end{array}$ \\
\hline $\begin{array}{c}\text { Supply chain } \\
\text { visibility }\end{array}$ & $\begin{array}{l}\text { provide precise and information on customer order status (exact availability, current status, and location of } \\
\text { their orders) by using Big Data analysis results (Kopp, 2013; Mehra, 2013) }\end{array}$ \\
\hline $\begin{array}{c}\text { Security and fraud } \\
\text { protection }\end{array}$ & $\begin{array}{l}\text { Loss prevention through the use of Big Data. With the help of the right infrastructure, such as Hadoop, e- } \\
\text { commerce firms can analyze data at an aggregated level to identify fraud relating to credit cards, product } \\
\text { returns and identity theft (Mehra, 2013). According to Akter \& Wamba (2016), "Visa has installed a big } \\
\text { data-enabled fraud management system that allows the inspection of 500 different aspects of a transaction, } \\
\text { with this system saving US\$2 billion in potential losses annually" }\end{array}$ \\
\hline $\begin{array}{c}\text { Predictive analytics } \\
\text { to address customer's preferences. Helps firms prepare budget, cognize future sales patterns (Mehra, } \\
\text { 2013). }\end{array}$ \\
\hline
\end{tabular}


Akter \& Wamba (2016) conducted a detailed study on the relevant theories in e-commerce and came up with six mechanisms to enhance practical business by using Big Data.

The six mechanisms are presented in Table 1. Table 2 shows that many e-commerce firms worldwide are able to enhance business value in the form of transactional, informational and strategic benefits by using Big Data analytics. Some other real-life examples of business value gained from the usage of Big Data are shown in the following table, Table 3.

Table 2: Business value of big data analytics in E-Commerce

\begin{tabular}{|c|c|c|c|}
\hline Source & E-Commerce Functions & Description & $\operatorname{Firm}(\mathbf{s})$ \\
\hline \multirow{5}{*}{$\begin{array}{l}\text { Manyika et al. } \\
\text { (2011) }\end{array}$} & $\begin{array}{l}\text { Predictive analytics (e.g., } \\
\text { market share analysis) }\end{array}$ & $\begin{array}{l}\text { Use of big data to capture market share from local } \\
\text { competitors. }\end{array}$ & Tesco \\
\hline & $\begin{array}{l}\text { Personalization (e.g., direct } \\
\text { marketing, relationship } \\
\text { marketing) }\end{array}$ & $\begin{array}{l}\text { Recommendation engine to generate 'you might also } \\
\text { want' prompts to generate sales. }\end{array}$ & Amazon.com \\
\hline & $\begin{array}{l}\text { Predictive and cluster } \\
\text { analytics (e.g., } \\
\text { segmentation, customer } \\
\text { profitability). }\end{array}$ & $\begin{array}{l}\text { Developed behavioral segmentation and a multi-tier } \\
\text { membership reward program by analyzing customer } \\
\text { profiles, real-time changes in customer behavior, and } \\
\text { customer profitability. }\end{array}$ & Neiman Marcus \\
\hline & $\begin{array}{l}\text { Personalization (email } \\
\text { marketing) }\end{array}$ & $\begin{array}{l}\text { Integrated customer databases with information on } \\
\text { some } 60 \text { million households to improve the response } \\
\text { rate of email marketing. }\end{array}$ & Williams-Sonoma \\
\hline & $\begin{array}{l}\text { Personalization } \\
\text { (customized service } \\
\text { offerings) }\end{array}$ & $\begin{array}{l}\text { Compiled detailed holistic customer profiles, and } \\
\text { conduct experiments and segment their customers } \\
\text { systematically and effectively to personalize product } \\
\text { offers and increase customer loyalty. }\end{array}$ & $\begin{array}{l}\text { Harrah's, Progressive } \\
\text { Insurance, Capital } \\
\text { One }\end{array}$ \\
\hline $\begin{array}{l}\text { (LaValle et al. } \\
\text { 2011) }\end{array}$ & $\begin{array}{l}\text { Predictive analytics (data- } \\
\text { driven customer insights) }\end{array}$ & $\begin{array}{l}\text { Collected } 80-90 \% \text { of the information possibly } \\
\text { needed about customers to generate analytics-driven } \\
\text { customer insights. }\end{array}$ & Best Buy \\
\hline $\begin{array}{l}\text { (Davenport et } \\
\text { al. 2012) }\end{array}$ & Dynamic pricing & $\begin{array}{l}\text { Is able to optimize pricing of } 73 \text { million items in just } \\
\text { over one hour. }\end{array}$ & Macys.com \\
\hline \multirow{2}{*}{$\begin{array}{l}\text { (Kiron et al. } \\
\text { 2012) }\end{array}$} & $\begin{array}{l}\text { Customer service (e.g., } \\
\text { service innovation) }\end{array}$ & $\begin{array}{l}\text { Uses personal profiles and psychology-based } \\
\text { analytics to help people connect and enter into a } \\
\text { loving relationship. }\end{array}$ & Match.com \\
\hline & Security and fraud detection & $\begin{array}{l}\text { Each new PayPal initiative across finance, } \\
\text { operations, and products is examined with quantified } \\
\text { impact and leveraging analytics. }\end{array}$ & PayPal \\
\hline $\begin{array}{l}\text { (Schroeck et al. } \\
\text { 2012) }\end{array}$ & Dynamic pricing & $\begin{array}{l}\text { Scheduling price reductions to sell perishable } \\
\text { products before they spoil. }\end{array}$ & Automercados Plaza's \\
\hline $\begin{array}{l}\text { (Chandrasekara } \\
\text { n et al. 2013) }\end{array}$ & $\begin{array}{l}\text { Cluster and predictive } \\
\text { analytics (segmentation) }\end{array}$ & $\begin{array}{l}\text { Systematically integrates analytics and consumer } \\
\text { insights using data from its Clubcard loyalty program } \\
\text { to better segment and target customer occasions. }\end{array}$ & Tesco \\
\hline
\end{tabular}

Adapted from Akter \& Wamba (2016) 
Table 3: Business Value Gained by Using Big Data

\begin{tabular}{|l|l|}
\hline $\begin{array}{l}\text { E-Commerce Firm } \\
\text { Name }\end{array}$ & \multicolumn{1}{c|}{ Business value gained by using Big Data } \\
\hline Amazon & $\begin{array}{l}\text { was able to make 30\% of its sales using the recommendation engine which is based on the Big Data } \\
\text { Analytics (The Economist, 2011). }\end{array}$ \\
\hline Match.com & was able to increase its profit by $50 \%$ in the past two years (Kiron et al., 2012). \\
\hline $\begin{array}{l}\text { Premier Healthcare } \\
\text { Alliance }\end{array}$ & was able to reduce expenditure by US\$2.85 billion by using the Big Data analysis tools (IBM, 2012). \\
\hline $\begin{array}{l}\text { United Parcel Service } \\
\text { (UPS) }\end{array}$ & $\begin{array}{l}\text { examines usage patterns and complaints data to accurately predict customer defections. This process } \\
\text { has resulted in a significant increase in customer retention for the firm (Davenport, 2012). }\end{array}$ \\
\hline
\end{tabular}

\subsection{Successful stories of big data}

In this section, we present how real world companies (e.g. Zillow) made use of Big Data.

According to Walker (2015), Yelp and TripAdvisor developed a website to help users choose the best restaurant of their choice. Primarily, the Yelp site was developed to help customers look for restaurants in urban areas, however, Yelp was later extended to also provide user-generated recommendations on different types of merchants. TripAdvisor started its business by providing valuable information that allowed their users to manage and enjoy an efficient trip without the aid of a travel agent. Both, Yelp and TripAdvisor, use Big Data for their business as well as for their customers.

Zillow, a real estate company, uses Big Data to help users access the required information to purchase properties and make real estate agents unimportant and irrelevant (Walker, 2015). Zillow's income is mainly generated from its Big Data based marketing business which includes subscriptions by agents and advertising by mortgage lenders. Following are the main features of Zillow's Big Data initiative:

- Over 77 million unique average monthly visitors

- 23 distinct mobile apps for consumers and real estate agents, across all platforms

- Database of more than 110 million US homes for sale, rent, and currently off-market

- 100 million high-quality images provided by customers and agents

- 460,000 ratings and reviews on premier real estate agents

- Over 800,000 housing professionals and experts on Zillow's Marketplace

- 20 million mortgage loan requests in 2013 with 58,000 reviews on mortgage products
Later on, Zillow further improved its Big Data applications to add more meaningful information to users. As a result, new products were developed. Some of these are listed in Table 4.

Table 4: Zillow Products

\begin{tabular}{|c|l|}
\hline $\begin{array}{c}\text { Product Name } \\
\text { Make Me }\end{array}$ & \begin{tabular}{l}
\multicolumn{1}{c|}{ Description } \\
allowed a current homeowner to invite \\
bids on their house
\end{tabular} \\
\hline $\begin{array}{c}\text { Mortgage } \\
\text { Marketplace }\end{array}$ & $\begin{array}{l}\text { a loan matching service for lenders } \\
\text { and borrowers }\end{array}$ \\
\hline Zillow Digs & $\begin{array}{l}\text { offer home remodeling information } \\
\text { like the new remodeled layout pictures } \\
\text { with prices etc. }\end{array}$ \\
\hline Zillow Data & $\begin{array}{l}\text { analyze housing information using } \\
\text { market factors like time, size of home } \\
\text { (one bedroom, two bedrooms, etc.), } \\
\text { zip code, and region and predictions } \\
\text { for property prices }\end{array}$ \\
\hline Mobile & $\begin{array}{l}\text { mobile phone application to help users } \\
\text { do house search when they are away } \\
\text { from their computers at home. }\end{array}$ \\
\hline
\end{tabular}

\subsection{Google and Big Data}

Following is a list of some of the early products of Google based on Big Data:

- $\quad$ AdWords in 2000

- Gmail in 2004

- Google Maps and Google Earth in 2005

- YouTube (through acquisition) in 2006

- $\quad$ Android mobile operating system(OS) in 2007

- Google Chrome browser in 2008

- Google+ in 2011 as an entry into the social networking marketplace 
Table 5: Google's Products

\begin{tabular}{|c|c|c|c|}
\hline \multirow{3}{*}{ Web } & Web Search & Search billions of webpages & Big Data \\
\hline & Mobile & Get Google products on a mobile phone & $\begin{array}{l}\text { Management of these is a Big } \\
\text { Data issue }\end{array}$ \\
\hline & Maps for mobile & $\begin{array}{l}\text { View maps, your location, and get directions } \\
\text { on a phone }\end{array}$ & Big Data \\
\hline $\begin{array}{l}\text { Search for } \\
\text { Mobile }\end{array}$ & $\begin{array}{l}\text { Search Google } \\
\text { wherever an } \\
\text { individual is } \\
\text { located }\end{array}$ & Potentially Big Data & $\begin{array}{l}\text { Big Data if number of users is } \\
\text { considered }\end{array}$ \\
\hline \multirow{5}{*}{ Media } & YouTube & Watch, upload, and share videos & Big Data \\
\hline & Google Play & $\begin{array}{l}\text { Your music, movies, books, and Android } \\
\text { apps available anywhere }\end{array}$ & Big Data in terms of storage \\
\hline & Books & Search the full text of books & Potentially Big Data \\
\hline & Image Search & Search for images on the web & Big Data \\
\hline & Video Search & Search for videos on the web & Big Data \\
\hline \multirow{4}{*}{ Geo } & Google Offers & $\begin{array}{l}\text { Get amazing offers at the best places to eat, } \\
\text { shop, and play }\end{array}$ & Possibly Big Data \\
\hline & Maps & View maps and directions & Big Data \\
\hline & Earth & Explore the world from a computer & Big Data \\
\hline & Panoramic & Explore and share photos of the world & Storage is Big Data \\
\hline \multirow{6}{*}{$\begin{array}{l}\text { Specialized } \\
\text { Search }\end{array}$} & Blog Search & Fid blogs on your favorite topics & Management is Big Data \\
\hline & Google Shopping & Search for products to buy & Potentially Big Data \\
\hline & Finance & $\begin{array}{l}\text { Business information, news, and interactive } \\
\text { charts }\end{array}$ & Potentially Big Data \\
\hline & Scholar & Search scholarly papers & Potentially Big Data \\
\hline & Alerts & $\begin{array}{l}\text { Get e-mail updates on the topics of your } \\
\text { choice }\end{array}$ & Potentially Big Data \\
\hline & Trends & Explore past and present search trends & Potentially Big Data \\
\hline \multirow{11}{*}{$\begin{array}{l}\text { Home and } \\
\text { Office }\end{array}$} & Gmail & $\begin{array}{l}\text { - } \quad \text { Fast, searchable e-mail with less spam } \\
\text { thanks to strong spam filters } \\
\text { - } \quad \text { Uses Google Search Engine } \\
\text { - } \quad \text { Substantial online storage for the } \\
\text { individual user }\end{array}$ & Storage is Big Data \\
\hline & Drive & $\begin{array}{l}\text { Create, share, and keep all your information } \\
\text { in one place }\end{array}$ & Storage is Big Data \\
\hline & Docs & Open, edit, and create documents & Management is Big Data \\
\hline & Sheets & Open, edit, and create spreadsheets & Management is Big Data \\
\hline & Slides & Open, edit, and create presentations & Management is Big Data \\
\hline & Sites & Create websites and secure group wikis & Management is Big Data \\
\hline & Calendar & $\begin{array}{l}\text { Organize your schedule and share events } \\
\text { with friends }\end{array}$ & Storage is Big Data \\
\hline & Translate & $\begin{array}{l}\text { Instantly translate text, web pages, and files } \\
\text { among and between over } 50 \text { languages }\end{array}$ & $\begin{array}{l}\text { Surprisingly, the algorithm } \\
\text { for this self-cleansing } \\
\text { translator may be a big data } \\
\text { project }\end{array}$ \\
\hline & Google Wallet & Make your phone your wallet & Storage is Big Data \\
\hline & $\begin{array}{l}\text { Google Cloud } \\
\text { Print } \\
\end{array}$ & Print anywhere from any device & Management is Big Data \\
\hline & Google Keep & "Save what's on your mind" & Management is Big Data \\
\hline
\end{tabular}


Table 5 (continued)

\begin{tabular}{|c|c|c|c|}
\hline \multirow{2}{*}{ Social } & Google + & Real-life sharing, rethought for the web & $\begin{array}{l}\text { At over half a billion users } \\
\text { this is Big Data }\end{array}$ \\
\hline & Blogger & $\begin{array}{l}\text { Share your life online with a blog-it is } \\
\text { quick, easy, and free }\end{array}$ & $\begin{array}{l}\text { Storage and management is } \\
\text { potentially Big Data }\end{array}$ \\
\hline \multirow{3}{*}{ Advertising } & Fusion Tables & $\begin{array}{l}\text { - Visualize, combine, host, and share } \\
\text { your data tables } \\
\text { - Spreadsheet/database with hundreds of } \\
\text { thousands of rows } \\
\text { - Charting, mapping, network graph } \\
\text { capabilities } \\
\text { - The search engine can search other } \\
\text { tables for table "mashups" }\end{array}$ & $\begin{array}{l}\text { Appears to be an application, } \\
\text { storage could potentially } \\
\text { become a Big Data issue }\end{array}$ \\
\hline & AdWords & $\begin{array}{l}\text { - } \text { Provides advertising copy on web pages } \\
\text { - } \quad \text { Controlled by Google in the Google- } \\
\text { verse } \\
\text { - } \quad \text { Cost per impression } \\
\text { - } \quad \text { Cost per click (CPC) }\end{array}$ & Big Data item \\
\hline & AdSense & $\begin{array}{l}\text { User choices drive what a user sees based } \\
\text { on: } \\
\text { - } \quad \text { Content } \\
\text { - } \quad \text { Feeds (e.g., really simple syndication } \\
\text { [RSS]), which allows web-based news } \\
\text { collection for subscribers } \\
\text { - Search } \\
\text { - Mobile content } \\
\text { - } \quad \text { Domains } \\
\text { - } \quad \text { Video } \\
\text { - Uses tracking cookies }\end{array}$ & $\begin{array}{l}\text { Targeted advertising and } \\
\text { definitely a big data item }\end{array}$ \\
\hline
\end{tabular}

Adapted from Walker (2015)

- Go programming language: designed for distributed processing. It may end up being a killer application for development on big data systems.

- Android: Released in 2008. Samsung has, to date, used Android as the OS for their cell phones and tablets. Almost three-quarters of all mobile users are using Android on their cell phones/tablets.

Not all Google products are using Big Data storage, some are only using the Big Data management tools and some are potential users of Big Data.

Table 5 shows the Google Product Offerings and the extent to which it uses Big Data.

According to Manyika et al. (2011), the effective use of Big Data has the underlying benefits to transform economies, and delivering a new wave of productive growth. Taking advantages of valuable knowledge beyond Big Data will become the basic competition for today's enterprises and will create new competitors who are able to attract employees that have the critical skills on Big Data. There are many business advantages that can be obtained through harnessing Big Data as illustrated in Fig. 1, including increasing operational efficiency, informing strategic direction, developing better customer service, identifying and developing new products and services, and identifying new customers and markets, etc. The vertical axis denotes the percentages that how many enterprises think Big Data can help them with respect to specific purposes.

For example, above $50 \%$ of 560 enterprises think Big Data will help them in increasing operational efficiency. According to Manyika et al. (2011), Big Data could produce $\$ 300$ billion potential annual value to US health care, and $€ 250$ billion to European public administration. There will be a $\$ 600$ billion potential annual consumer surplus from using personal location data globally. Big Data produces 140,000 to 190,000 deep analytical talent positions and 1.5 million datasavvy managers in the United States. 


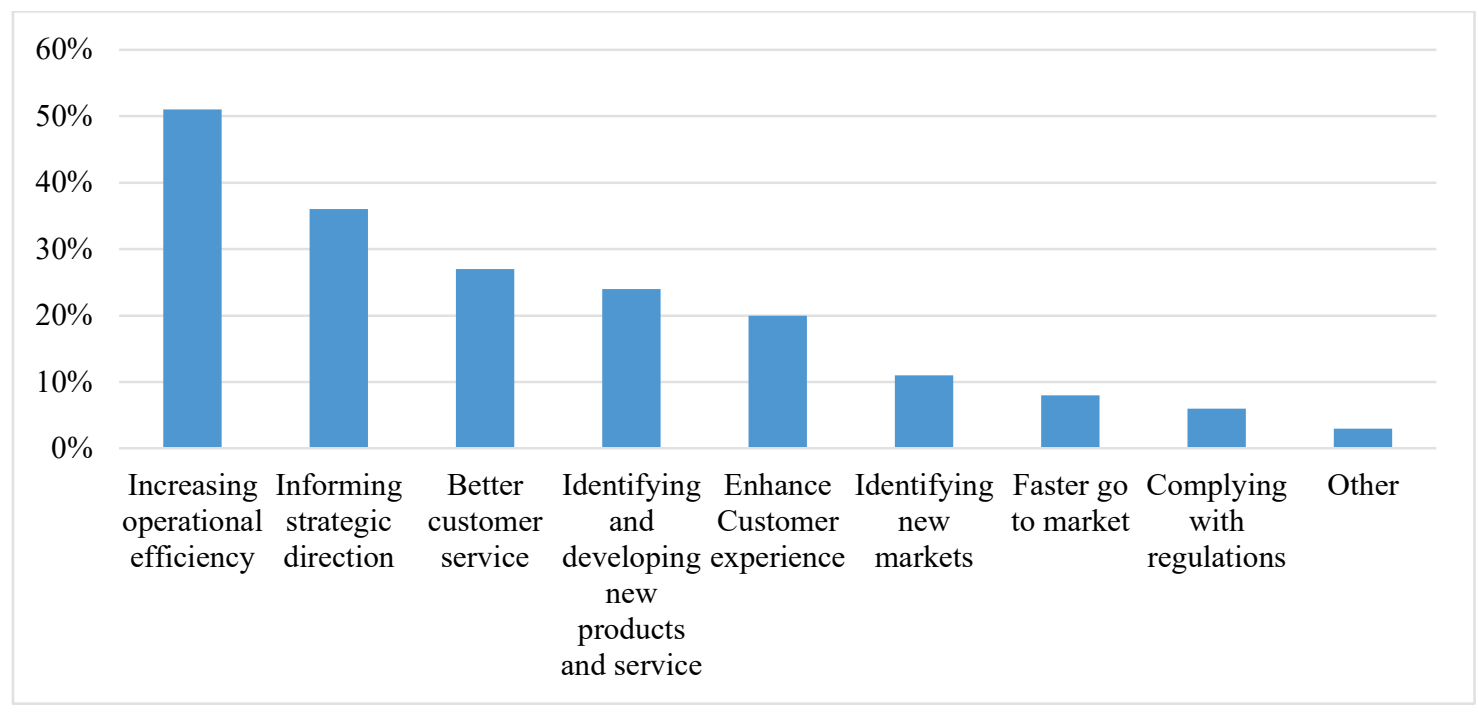

Fig. 1. Big Data Advantages.

\section{The Application of Big Data in Businesses}

In this section, we discuss applications of Big Data in several businesses.

\subsection{The Application of Big Data in Human Resource Management}

\subsubsection{Big data application in recruitment of talent}

One of the main jobs that the Human Resource department is required to do is to hire a candidate who is fit for a position. The old traditional selection process has a big drawback; it depends on the information that a recruit has provided which is not enough to completely judge the abilities of the recruit for the job. Therefore, the results from this selection process are usually biased due to the Human Resource department lacking some information needed to choose a suitable candidate (Huang et al., 2013). The introduction of Big Data and tools made it possible to collect more information from the internet and analyze that information to make an unbiased decision in the selection process. For instance, most companies in China use the online recruitment process (based on Big Data) to hire new candidates according to statistics. Social media networking now also plays a role in the recruitment process. It helps the HR management to collect information about potential candidates. This provides a solid base for Big Data analytics and this makes the recruitment process more reliable (Dong et al., 2014).

\subsubsection{Big Data application in talent training}

According to research, the training of employees by organizations is a major role played by Big Data. The traditional method of classroom training needs more human and financial resources, however, the introduction of Big Data makes employee training more efficient and less costly. This was made possible because information processing and sharing was made easy by Big Data. Organizations have created training courses and uploaded it onto their network allowing employees to take those training courses at any time. Companies can purchase software to train their employees, which can also be customized according to an organization's needs. Additionally, the organization's management can use the software to monitor their employees' study behavior. Employees can take online tests whenever they want to and they can submit it to the organization allowing the management to analyze the learning curve of employees (He, 2013).

\subsubsection{Big data Applications in employee career management}

Quantitative analysis of employee information (i.e. performance, professional experience, interest during duty, promotion etc.) is another important feature of Big Data applications. This allows Human Resources to better understand the employees' career interests and 
therefore provide assistance with the employees' career planning and management (He, 2013).

\subsection{Big data applications in customer relationship management}

Big Data is used for retrieving information about customers' likeness and why they buy a particular product. This allows users to make more informed decisions. Furthermore, Big Data helps companies focus on customer needs, product development, and new openings for sale. All types of companies and businesses such as Business-to-business (B2B), business-to-consumer etc. can benefit from using Big Data. For instance, a company named DocuSign (offers digital transaction management services) made a profit of $\$ 6.5$ million in a few months after starting to use Big Data (Glass \& Sean, 2014).

Glass \& Sean (2014) came up with the following five lessons:

(i) Due to the use of Big Data, marketing department became more important since it attracts more customers. Now, companies can accurately and easily find out information about people who access their websites, people who read email newsletters, and potential customers.

(ii) With the use of Big Data, marketing technology is becoming more important. Companies use software like marketing automation technology, CRM systems, and analytics tools to help customers get more information about products. Thus, the marketing department of a company needs to work closely with the IT team.

(iii) Marketing team efficiency improved as a result of having insight of the customer and the ability to identify the best marketing qualified leads (MQLs) by using their marketing automation software. MQLs are immensely important for businesses; therefore, the most forward looking sales teams are working closely with the marketing department.

(iv) Big Data has proved its importance by helping the marketing department measure its programs. The marketing department can now increase and prove the company's value through social media, displaying ads, and mobile spending.

(v) The position of Chief Marketing Officers (CMOs) have become indispensable because of the use of Big Data in marketing.

\subsection{Big data applications in innovations}

Big Data and analytics usage has the ability to help organizations solve business challenges and produce innovation. Additionally, Big Data and analytics have become a crucial element in the seeking of innovation for organizations according to data from the 2014 innovation survey of more than 1,000 business leaders conducted by the IBM Institute for Business Value (Marshall et al., 2015). To outperform competitors, leading organizations are investing in innovation that will benefit them with chances to collect new data and combine external and internal data. For instance, leading companies are producing competitive advantages by using technological capabilities which allow them to predict and better meet customer needs.

Researchers studied 341 respondents' usage of big data and analytics tools for innovation to understand how leading organizations innovate (Marshall et al., 2015). The questions the researchers asked consisted of information about innovation goals, metrics used to measure innovation outcomes, barriers to innovation, treatment and types of innovation projects and the role of Big Data and analytics in innovation processes. As a result, researchers found three distinct groups: leaders, strivers and strugglers (Marshall et al., 2015). Leaders use Big Data and analytics with a structured approach to innovate and they also focus on collaboration. Strivers invest in tools that support innovation for specific functions, yet they are still uncertain about which activities are the most important for innovation. Strugglers are the weakest in innovation out of the three groups. They do not have a formal innovation process and face other internal challenges. However, when they do innovate, it usually occurs in isolated pockets due to their risk averse nature.

\subsection{Big data applications in accounting}

Big Data has very important effects on accounting, even while new types of data become accessible. Video, audio, and textual information made available through Big Data can allow financial accounting, managerial accounting, and financial reporting practices to improve (Warren, et al., 2015). For example, in financial accounting, Big Data will improve the relevance and quality of accounting information; thus, this will enhance transparency and stakeholder decision making. In managerial accounting, using Big Data will 
contribute to the evolution and development of effective management control systems and budgeting processes. Moreover, in financial reporting, Big Data has the ability to help with the creation and refinement of accounting standards.

Big Data could be very influential on the future of financial reporting and development in generally accepted accounting principles. The forms of Big Data such as video, audio, images, and text, can provide improved usefulness and transparency for decision making. For example, in terms of fixed assets, electronic resource planning systems can augment records with types of multimedia such as video clips. Through this process, users can obtain a more complete view of each asset's features, characteristics, and condition. This provides benefits to stakeholders and auditors tackling pertinent assertions about fixed assets. For instance, an auditor who is seeking to test the existence assertion relative to fixed assets could do so with ease if each asset record was accompanied with relevant video, audio, and textual information. These data can be analyzed to detect irregularities or outliers by using data mining. This will help in assisting management, auditors, and other stakeholders.

\subsection{Big data applications in policy decision making cycle}

High quality decision making depends on high quality information. However, fixing the quality of total information while merely increasing attribute information will result in the decrease of decision quality (Keller \& Staelin, 1987). This relationship results from the flashflood of information; intended because of a failure of filters, separated noise from relevant information, provided that it will take longer for decision making and will make the decision model more complicated, as more data and information is becoming available in the decision process. Knowing that hardly any information can be deleted, an increase in objection to apply for filters has been witnessed to reduce the complexity of problems. Potentially meaningful information falls in the category of data declared as noise, according to Big Data claims; yet the modern techniques and algorithms used to collect the beneficial information for noise are not used commonly. Big Data, and specifically Big Data Analytics (BDA), guarantees insights much more rapid and superior; provided that using machine learning algorithms interactions can be deduced automatically, data can be observed in much detail and the analytical results instantly become accessible in theory. In the policy cycle process steps we will describe the capability to acknowledge before time the adverse effects of a decision, which is a relative advantage of applied BDA.

\subsection{Big data application in supply chain}

Supply Chain Analytics (SCA) is the Big data based concept that is applied in all stages of businesses (sourcing, supply chain, and product design and development). SCA application helps managers in making informed decisions, understanding new marketing trends, identifying and assessing risks, and leveraging supply chain capabilities to formulate supply chain strategies which ultimately improve businesses both in terms flexibility and profitability. The benefits of using SCA have been realized by businesses both at a tactical and operational level. SCA helps managers analyzing and measuring supply chain performance on demand planning, procurement, production, inventory, and logistics. Hence, SCA is useful for improving organizations operations efficiency, measure supply chain performance, reduce process variability, and implement the best possible supply chain strategies at the tactical and operational level. These improvements are achieved through seamless interconnected operations between supply chain processes from the suppliers of raw materials to end customers.

\subsection{Developing a customized approach to using Big data}

Overcoming the use of analyzed data into a business insight has been a challenge due to the technical processes that are used to process information from the raw data. The complication results from the fact that the synthesis tools developers lack the business touch and their target may be just processing information from a bulk of raw data. As witnessed by many firm leaders, the information, though prepared, is still of no use unless the data is regenerated using a business approach. The process of regrouping data into a format that is meaningful to business persons entails adding value to the processed information, as well as providing insight, which can be used as a business information. Several approaches have been developed; that are meant to ensure that processed information makes sense and is useful to business leaders. 
Toolkits for open innovation remains an efficient customization method as directed by Hüsig and Kohn (2011). The toolkits can be customized to serve the needs of a given business company. When the information is customized, it is a resourceful information once acted upon. Open source toolkits may also give the potential users a chance to experience and experience their desires. Feedbacks obtained from these online trial versions of products ensure that businesses produce exactly what the consumers want and nothing less. Resultantly, the producer can avail what is needed for a given group of users; that can be grouped based on age, region, culture and economic class.

Manufacturers that use these pre-production techniques never go out of business; they are product leaders. This is the greatest advantage of real-time information processing software. McAfee et al. (2012) say that businesses with such powerful analyzing tools get to enjoy a monopolistic kind of market before their competitors can copy their products and create competition. Additionally, the business leaders become well informed on what the market wants. This improves their level of customer satisfaction, as well as the acceptability of their products, for they are in line with the needs of the consumers. This phenomenon is what Diener and Pille (2010) refer to as the Open Innovation Accelerators (OIAs). The key role of the OIA is to use the mass consumers, through the Internet, to define and identify business ideas. Having selected the viable business opportunities, they provide technological platforms that allow interaction with the market, for proper development of the defined concept. The development of the chosen idea happens as a result of interaction between the innovation community and the business entities supposed to develop the concept into a product (Hüsig \& Kohn, 2011). This communication ensures that correct approach to product development is taken, by considering all factors that had been tabled by the masses.

This process is bound to overcome the technical and business differences as the two entities will merge as the new product is formed. Having used the analyzed data means that a developed product will reflect the needs of the market as indicated in the Big Data. On the other end, the value of the created product will be high as it will adopt the business models of product development. Therefore, using the big data sourced information, analyzing the information with a combination of a business model will reveal a real business insight. Product development from the idea will lead to the production of value-added goods; such products will enjoy awaiting customers and therefore enjoy many willing buyers. This is a crucial, survival strategy, given the dynamic nature of current markets and the competitive development in the business world.

\section{Discussion}

Having explored the critical application of Big Data information product development and the overall performance of firms, it is clear that the importance of this recent development goes beyond mere business performance improvement to the survival of any business. The application of Big Data, especially in the era of web 2.0 has become a resourceful tool in getting together business partakers, consumers, and producers. McAfee et al. (2012) explain that the biggest setbacks that companies will encounter are challenges of exploiting the vast data resource due to poor leadership. The managers are blind never to see insightfully; the chances presented to them using the information. The authors indicate that there is a need for insight and a clearly set vision that will enable the leaders to see the changes in the market and what the consumers want.

Insight, in business, must be the unsought or the extraordinary thing. Developing such a concept is hard, as the memory will keep redirecting one's mind to what is already present or has ever been seen. However, Bollier and Firestone (2010) ascertain that Big Data has helped many people change from what they think is going to happen to what will happen, using accurate predictive measures. This is the real concept of insight, thinking beyond the norms in a way that will add value to your business. However, developing this new truth will demand a roadmap with the help of data points and toolkits so that the result will be a decision-making theory (Bollier \& Firestone, 2010).

On the other side, the value added by the information can only be exploited if consequential actions are taken, in response to the data. Most business organizations still fail to identify the best course of action that they ought to take due to poor information management. On this wake, McAfee et al. (2012) emphasize that companies must be ready to adapt to the dynamism of business information, as it reflects the dynamic nature of the market. Evolving with time will thwart the negative influence, of this, was not invented here, syndrome. 
In a deterministic model, McAfee et al. (2012) indicate that there is evidence beyond doubt, to prove that leaders have no choice but to embrace the use of Big Data information analyzing techniques in their management policies. Leaders who do not accept this fact will be forced out of business. Equally business entities that will not use the information sourced from Big Data in a strategic way will be out-competed by those that use the resource. While integrating this technological development demands more resources and expertise, the cost incurred have proven viable given the benefit reaped after using the information (Hüsig \& Kohn, 2011). However, what matters is how the information is synthesized.

Customization remains a key factor that will sieve sensitive data from petabytes of collected, yet useless data. Customization and proper understanding of the data can only be developed if a company understands its goals and has set some clear visions that will lead to the selection of valuable data (Bollier \& Firestone, 2010). Otherwise, loads of data may appear lucrative and many gaps may present while adapting to every developed idea will be expensive as many resources have to be changed. The quest to make the data mining software as close as possible to humanistic social interactive tools makes customization the best method ever. However, while the human mind has not been achieved through programming, modifying a particular system to analyze data in a specific way make the tools efficient compared to just running mere numbers with simple correlation (Bollier \& Firestone, 2010).

An insightful example of the dynamic nature of the market is the mobile phone manufacturer. The industry has been faced with highly dynamic business aspects. For instance, the rate of change of smartphone phone specifications is alarming, in that no phone remains in the market for more than five years. The highly competitive nature of the business has seen the manufacturing companies be faced with a challenge of the dynamism as they have to develop new technology and add new features in their phones upon every released brand (Bollier \& Firestone, 2010). Common factors that have been changing are the camera megapixel specification, battery charge capacity, and random access memory size. Companies such as Nokia, which are not keen with market trends have loosed a significant market share in spite of a spectacular performance, years ago.

\section{Conclusion}

In conclusion, Big Data's impacts, effects and influence on businesses, firms and e-commerce today is still growing to a larger extent, in a variety of different ways. Big Data, which is essentially the careful organization of large quantities of data in order to better equip and assist businesses for success, has become increasingly relevant and useful in a variety of ways for businesses.

Big Data resource has changed from being an extra advantage for any business to a critical asset that any company that wishes to compete in commerce must embrace. The primary role of Big Data is to generate critical information that can be used to add value to the production of goods, marketing and general public relations.

While the information sourced from this technology can lead to a great success of business, there is an equal chance of failure, upon acting on the information or not working on the info at all. The results obtained from acting on the information depends on how accurate the information is and the strategic nature of the actions taken (Hüsig \& Kohn, 2011). Evaluation of an identified business opportunity is critical; the risk increases when the idea if new and has never been tried by any other business. Under such a situation, it is hard to tell the results, even though simulations may have been conducted and indicate promising results.

From the most obvious impact of increasing the bottom line of a business, to assisting the human resources department of a firm, Big Data essentially becomes an added weapon or tool for firms in terms of their development moving forward. Specific evidence of this is shown through the successes of Big Data in various ways such as; enhancement in marketing and discovering consumer behavior patterns, increasing efficiency while at the same time reducing costs, assisting businesses in finance and accounting, and providing businesses a basis of which to innovate, grow and develop their firms into larger entities due specifically to the large informational value Big Data provides.

All in all, a strategic business venture is bound to yield positive results, as previous calculations of the risk ought to be performed. Many firms have increased their performance value through the incorporation of information technology, epically information sourced from the web. 
Additionally, the dynamism of businesses will lead to more exciting ventures, some of which may be more fortunate than others. What remains critical is the ability to develop a systematic strategy, in line with the companies' visions, and exploit the information from the internet to make fortunes.

Furthermore, several large firms highlight their success stories using Big Data which further proves the rise to popularity Big Data has had, and continues to have. Finally, the knowledge and information provided by Big Data will slowly become more crucial and essential as it will be the focal point of new basic competition between firms.

Having satisfied the two challenges is the main agenda that the paper seeks to settle. However, there remain critical problems that ought to be addressed. Among them is a proper procedure that ought to be used when developing the business particular sifting method for the data that combines the vision of an entity with the projected future commercial dynamisms. As along as human minds have not been developed in software from, customizing and narrowing the search region for the data mining software remains a critical path for extracting meaningful data from the petabytes available. Being able to see around the corner remains a key challenge, especially it determines which changes are going to last a while and are viable to adapt. This problem has made many businesses reluctant in adapting to changes that they think will be temporary, while other adjust a bit too soon, only to detect a reversal of the situation. Changes come with profound economic expenses, as resources become obsolete and no more useful. Having a method that can detect future market changes, and relate them to the business agenda is critical (Bollier \& Firestone, 2010). Therefore, this area demands more research.

\section{References}

1. Agarwal, R., \& Weill, P. (2012). The benefits of combining data with empathy. MIT Sloan Management Review, 54, 35.

2. Akter, S., \& Wamba, S. F. (2016). Big data analytics in E-commerce: a systematic review and agenda for future research. Electronic Markets, 26(2), 173-194.

3. Beath, C., Becerra-Fernandez, I., Ross, J., \& Short, J. (2012). Finding value in the information explosion. MIT Sloan Management Review, 53, 18-20.
4. Bollier, D., \& Firestone, C. M. (2010). The promise and peril of big data (p. 1). Washington, DC: Aspen Institute, Communications and Society Program.

5. Columbus, L. (2014). Making analytics accountable: 56\% Of executives expect analytics to contribute To $10 \%$ Or more growth in 2014, Forbes.

6. Bose, R. (2009). Advanced analytics: opportunities and challenges. Industrial Management \& Data Systems, 109, 155-172.

7. Chandrasekaran, S., Levin, R., Patel, H., \& Roberts, R. (2013). Winning with IT in consumer packaged goods: Seven trends transforming the role of the CIO. McKinsey \& Company, 1-8.

8. Davenport, T.H., (2012). The Human Side of Big Data and High-Performance Analytics. International Institute for Analytics, 1-13.

9. Davenport, T. H., Barth, P., \& Bean, R. (2012). How 'Big Data'is Different. MIT Sloan Management Review, 54, 43-46.

10. Diener, K., \& Piller, F. (2010). The market for Open Innovation: first study to compare the offerings, methods, and competences of intermediaries, consultancies, and brokers for open innovation. RWTH-TIM Group.

11. Dong, X. H., Ying, A., \& Guo, J. G. (2014). Research on the Application of the Big Data Technology in the Network Recruitment. Human Resource Development of China, 18, 37-41.

12. Gantz, J., \& Reinsel, D. (2012). The digital universe in 2020: Big data, bigger digital shadows, and biggest growth in the far east. IDC iView: IDC Analyze the future, 2007, 1-16.

13. Glass, R., \& Callahan, S. (2014). The Big Data-driven business: How to use big data to win customers, beat competitors, and boost profits. John Wiley \& Sons.

14. He, Y. (2013). Management Innovation in "the Era of Big Data". Human Resources, 10, 62-63.

15. Hüsig, S., \& Kohn, S. (2011). "Open CAI 2.0"-Computer Aided Innovation in the era of open innovation and Web 2.0. Computers in Industry, 62(4), 407-413.

16. Huang, S.L. and Xiang, J. (2013). "Big Data" Light up "Wisdom" of Human Resources Management System. Science \& Technology for Chinese Mass Media, 12, 7678.

17. IBM, (2012). What is big data? Available at: http://www01.ibm.com/software/data/bigdata/what-is-big-data.html (Accessed $19^{\text {th }}$ of August, 2016).

18. Jao, J., (2013). Why big data Is A must in ecommerce. Available at: http://www.bigdatalandscape.com/news/ why-big-data-is-a-must-inecommerce (Accessed 6th of July, 2016)

19. Kandogan, E., Roth, M., Kieliszewski, C., Özcan, F., Schloss, B., \& Schmidt, M. T. (2013, June). Data for All: A Systems Approach to Accelerate the Path from Data to Insight. In 2013 IEEE International Congress on Big Data (pp. 427-428). IEEE. 
20. Keller, K. L., \& Staelin, R. (1987). Effects of quality and quantity of information on decision effectiveness. Journal of consumer research, 14(2), 200-213.

21. Kiron, D., Shockley, R., Kruschwitz, N., Finch, G., \& Haydock, M. (2012b). Analytics: the widening divide. MIT Sloan Management Review, 53, 1-22.

22. Kopp, M., (2013). Seizing the big data opportunity, Ecommerce Times.

23. Kung, D. S., Gordon, L. C., Lin, F., Shayo, C., \& Dyck, H. (2013). IT-based System with Dynamic Pricing Algorithm. Business Journal for Entrepreneurs: Business Analytics.

24. LaValle, S., Lesser, E., Shockley, R., Hopkins, M. S., \& Kruschwitz, N. (2011). Big Data, Analytics and the Path from Insights to Value. MIT Sloan Management Review, $52,21-32$.

25. Manyika, J., Chui, M., Brown, B., Bughin, J., Dobbs, R., Roxburgh, C., Byers, A.H., (2011). Big data: The next frontier for innovation, competition, and productivity.

26. Marshall, A., Mueck, S., \& Shockley, R. (2015). How leading organizations use big data and analytics to innovate. Strategy \& Leadership, 43(5), 32-39.

27. McAfee, A., Brynjolfsson, E., Davenport, T. H., Patil, D. J., \& Barton, D. (2012). Big data. The management revolution. Harvard Bus Rev, 90(10), 61-67.
28. Mehra, G., (2013). 6 uses of big data for online retailers, Practical Ecommerce.

29. Miller, G., (2013). 6 ways to use "big data" To increase operating margins by $60 \%$.

30. Walker, R. (2015). From Big Data to Big Profits: Success with Data and Analytics. Oxford University Press.

31. Schroeck, M., Shockley, R., Smart, J., Romero-Morales, D., \& Tufano, P. (2012). Analytics: The real-world use of big data. IBM Global Business Services, 1-20.

32. The Economist, (2011). Building with big data: The data revolution is changing the landscape of business.

33. Warren Jr, J. D., Moffitt, K. C., \& Byrnes, P. (2015) How Big Data will change accounting. Accounting Horizons, 29(2), 397-407.

34. White, M. (2012). Digital workplaces Vision and reality. Business information review, 29(4), 205-214.

35. Wixom, B. H., Yen, B., \& Relich, M. (2013). Maximizing value from business analytics. MIS Quarterly Executive, $12,111-123$.

36. Zhao, D. (2013). Frontiers of big data business analytics: patterns and cases in online marketing. Big Data and Business Analytics, 43. 